\title{
Editorial
}

\section{The Great Advisor}

Journal of Financial Services Marketing (2006) 11, 95-98. doi:10.1057/palgrave.fsm.4760034

The message is clear: Transactions are out. Advice and relationships are in for today's investors and financial professionals.

The old 'greed them in and scare them out' transaction model is fast becoming an absurdity. Technology has already made transactions a low fee, commodity business. Moreover, the complexity of client needs is creating an extraordinary opportunity for those who can truly advise.

Yet today's clients need more than a personality, a product pitch and a crushing close. They need real advice from professional advisors who will get them to do what they ought to do, when they are reluctant or afraid to do it. They need a Great Advisor.

The change in business models has been occurring for a while. Advertising slogans ooze with client concerns, focus on fulfilling client dreams and allaying client fears. Business cards now say 'Advisor' or 'Consultant' rather than 'Stockbroker', 'Investment Sales', or 'Rep.'

Still, this evolution from a transaction mindset to that of Advisor will take more than a new marketing plan. It requires firms to change their training, fee structures, compensation schemes, and attitudes. To their credit, firms are making these changes and that is no small accomplishment.

Now comes the hard part: Firms and clients alike must 'get it' below the neck in their culture, their heart, their core, and so on, right down to their DNA.

\section{A ROLE MODEL}

Let's examine the existing role models. Who are the most trusted advisors at work today? Even with the tendency toward internetdriven self-diagnosis, by far the most trusted advisors in society are medical doctors.

Doctors tell us what to do in matters of life and death, even when they may not be 100 percent sure of what they advise.

Medicine is, after all, part science and part art. Doctors understand that they must take educated risks because human nature leads people to ignore vague 'maybe/possibly/sortof' treatment recommendations. Therefore, even in the face of malpractice suits, doctors have the courage to tell us what to do.

The respect that patients give their doctors is impressive. And the model they use can greatly benefit the Advisor. The key is to follow The 7 Rules of Selling.

\section{Rule \#1: Establish Your Credibility}

Medical doctors have credibility and their clients tend to listen. So, establish credibility with yourself first and then with your clients. Remember: When they think you know the answers, they don't ask the hard questions.

Credibility is the critical context of communications and relationships. It is the foundation of successful sales relationships and winning relationships for financial advisors. Credibility creates a condition in which you can control the process. With credibility, people listen. Without it, they hesitate, question, discount, and sometimes just walk. 
Genuine long-term credibility comes from being honourable, reliable, trustworthy, and, of course, delivering the intended result. Nevertheless, don't neglect the little things that are essential to your having a chance to show the world just how honourable, reliable, trustworthy, and good you are. Make sure you present yourself and your message in a way that supports your credibility.

\section{Rule \#2: Know Your Product}

These days, a superior product rarely provides a lasting advantage. In fact, competitive products are equalizers, essential for playing the game but rarely for maintaining an upper hand long term.

Thanks in large part to the internet, hoarding an information advantage is nearly impossible. That is why Advisors have to focus on bringing their own unique additions to the value proposition. While your product is everything you and your company offer, to a great degree it all boils down to the advice given and your ability, integrity, and concern for your clients.

Clients need Advisors who will bring a unique value, who listen, who understands their situation, and who knows the world of money so well that they can simplify it.

\section{Rule \#3: Know Your Client}

You can never know too much about your client. So ask questions and genuinely listen to the answers. Information will help you target your message, establish the relationship, overcome objections, recover from mistakes, and, most importantly, help your clients meet their goals.

The answers to your questions should reveal all the standard information about their assets, income, family demographics, and risk tolerance. Now take it a bit further by asking questions that give you a deep understanding of their 'inner investor'. What are their hopes, dreams, and fears? Ask open-ended questions and then quiet down and let them talk.
Practice 'deep listening'. Don't just hear what they say; hear how they see it and how they look as they say it. Don't just wait for them to stop speaking so you can talk. Don't listen to find an angle and don't think about what you are going to say next.

Be fully present for your clients. Participate as you listen. Hear their words and the story behind those words. Even adjust your body and your tone as you feel the impact of their words. Then, ask more questions.

Busy as they are, good doctors listen. They want to know our vital signs before they even talk to us. Then, they put their stethoscope on our chest and listen. Then they ask more questions: 'What else?' 'Is there anything more?' 'Is there anything you are not telling me?' Those questions and our answers help doctors advise us and makes us more comfortable with them.

\section{Rule \#4: Keep it Simple}

Jazz great Thelonius Monk captured the essence of the problem when he succinctly said: 'Simple ain't easy'.

The ability to communicate complex issues in a simple and effective manner is a critical sales skill. Simplistic is easy. Simple requires a deep understanding of the subject and an intellectual self-assurance.

Great doctors and great Advisors have sufficient credibility, product knowledge, and client understanding to move beyond simplistic. They can account for complexities, strip away the unnecessary entities, and deliver the simple truth to their clients.

Here are a few quick steps to simplicity:

Keep it Down to Earth: Never use big words and fancy phrases when simple words will do. Whenever possible, use terms, phrases, and analogies to which the client can relate.

Think: If it takes a lot of big words or complex formulas to express a thought, give it more thought.

Avoid Creeping Growth: Presentations have a way of growing gradually. You prepare the 
perfect $15 \mathrm{~min}$ presentation and it works. A week later you see an idea in a paper and you add it. It only adds $2 \mathrm{~min}$, but now you have a $17 \mathrm{~min}$ presentation that you are rushing to complete. And so it grows ...

\section{Rule \#5: Stress Concepts and Benefits}

What's the difference between a feature and a concept? Features are the 'characteristics' of a product or service that make it prominent or distinctive. They are what a product or service is made of: its structure and form. A concept is less specific. It is an idea, a notion, an impression. It is aimed less at the head and more below the neck. A step above features, concepts allow for different formulations from individual to individual and are an integral part of the Advisor's role. Doctors stress concepts and benefits that get to the heart of the matter, the classic example of which is when the doctor says: 'Do it, or die!'

Great Advisors expand their skills to include the ability to stress concepts and benefits. Concepts such as service, quality, and a continued commitment to excellence.

\section{Rule \#6: Communicate Enthusiasm, Certainty, and Commitment}

When you are advising clients, there is indeed much technical information that needs to be communicated head to head. But, relationships are built from trust and at the heart level. It's at that level where Advisors can best communicate their enthusiasm for what they do, their certainty of their qualifications to do it, and their commitment to clients.

Firms fight the battle for client trust and relationships with hard side weapons like cutting edge products, outstanding research and stellar service. Yet, these days those are just table stakes. It is the Advisor's relationships that win the war. In other words, it is the so-called 'soft side' that tips the scales and makes the difference.
There are many clients for whom the soft side rules. They work with Advisors they like. A similar dynamic is present in medicine. Study after study has shown that patients are much less likely to sue a doctor they like than one who treats them poorly. Clearly, some clients carefully analyse every decision. Yet, in most cases, even those clients end up on the 'soft side.'

\section{Rule \#7: Take a Chance}

To be a long-term success, Advisors must take chances. That does not mean being reckless with client accounts. It means having the courage to try new ways of being, acting, and thinking. It means going beyond canned or habitual presentations. Instead, ask clients questions and listen to their answers without bias or expectation. Hear them and then take the conversation where they need it to go. That will probably feel risky, but it is necessary to give clients the service they need and deserve. Doing that after all is the only way to assure your own long-term success as an Advisor.

Advisors must be current, fresh, and innovative. So, transcend the ordinary. Let your clients' needs and questions help you create new ideas and custom approaches. Serve your clients as individuals, not stereotypes, and do so in an innovative, original, resourceful, and even inspired way. That's taking a chance, but more is needed.

To advise clients, you must not only ask questions and listen to the answers. You must take stands and tell your clients what to do. Investors are so overloaded with news that many clients are thought-flooded. With so much information and misinformation coming their way, they cannot process it. So they freeze or act erratically. Advisors can and should help clients steer a steady course, sorting out the 24/7 torrent, and refocusing the investor's attention on what's important.

Clients and prospects need advice more than they ever have, but they don't need you to 'ask for the order' any longer. They need 
you to do as a doctor would, and strongly direct them in their decisions.

\section{MARKETING SLOGAN OR CULTURE CHANGE}

Will the move from transactions to advice be a mere marketing plan or a change in the character of the business? Is the term Advisor merely a euphemism, or is it a role change?

Embrace the role change and make the investment beyond your business card title or marketing slogan. Become your clients' 'doctor' of financial advice. Do the listening and questioning necessary to become your most trusted valuable professional self, and then provide instruction on matters of their financial health. Your clients will feel safe and comfortable taking your advice to heart.

Alan Parisse is one of the most highly sought-after speakers in financial services today, with ideas quoted in The Wall Street Journal, Business Week, Barrons,' and Executive Excellence. This paper is a brief excerpt from his new audio CD series, The Great Salesperson: The Ultimate Guide to Influencing Others. His latest book, Questions Great Financial Advisors Ask... has just been released. For information on products and programmes, visit Alan online at www.parisse.com.

\section{Alan Parisse The Parisse Group}

